\title{
State Support for Local Election Offices
}

\author{
Lori Augino
}

\begin{abstract}
Cooperation and coordination between state and local election offices is an integral part of election administration. Ensuing that the expertise of local government officials is integrated into decision-making processes is one of many ways to solidify a strong relationship between the state and local governments. Presented are the processes that are used in the state of Washington to ensure that the state election office is providing support to local election officials and implementing policies that enhance the administration of elections and the voter experience in the state.
\end{abstract}

Keywords Collaboration • Training • Help America Vote Act - Equipment • Intergovernmental relationships • Resources

Both Secretary of State Kim Wyman and I are foundationally local election officials. I served for 18 years in Pierce County, and Secretary Wyman served as Auditor in Thurston County. As a result, we have a deep understanding and appreciation for the work that local officials do. From the first day we walked in the door of the Office of Secretary of State, we wanted to ensure that this office served our local election officials to give

L. Augino $(\bowtie)$

Washington Secretary of State, Olympia, WA, USA

e-mail: lori.augino@sos.wa.gov

(C) The Author(s) 2019

M. Brown et al. (eds.), The Future of Election Administration, Elections, Voting, Technology, https://doi.org/10.1007/978-3-030-18541-1_14 
them a strong voice in what happens across the state. We worked from the beginning to include the perspectives of local officials in building a statelevel structure to support those local officials. We had experienced seeing the state office at odds with the counties, and we wanted to avoid that as much as possible.

In my role as Washington's Director of Elections, I have stressed that my office is a resource for local offices. We are not adversarial; we are here to help. We respect the boots-on-the-ground experience and abilities of the county auditors and local election officials, as well as the deep commitment that they bring to elections across the state.

The Elections Division of the Office of Secretary of State contains three divisions-certification and training, voter information services, and election law support. In addition, we have open and regular communications with the county offices. All of this work is supported by a combination of state general funds and federal support from Help America Vote Act (HAVA) funds. Our efforts are described below.

\section{Certification And Training}

The cornerstone of our efforts is certification and training, for which we partner with county auditors. We pride ourselves in having a dynamic and well-run statewide training program. Our state law requires having at least two certified election officers in each county. Certification credentials are earned through initial and ongoing training, with a Washington statespecific component to ensure that election administrators are well-versed in what happens across the state. This builds consistency in how elections are conducted throughout Washington. The components of the initial training for Certified Elections Administrator are listed below and include a combination of class-based training sessions, individual work, and onthe-job experience.

\section{Washington Certified Elections Administrator REQUIREMENTS (JANUARY 2019)}

- Attend a two-day orientation class

- Pass the Administrator Certification exam

- Receive an additional 40 hours of education 
- 30 of these must be election-specific and offered by approved sponsors such as

Washington Association of County Auditors (WSACA)

Office of the Secretary of State (OSOS)

Election Center (www.electioncenter.org)

United State Election Assistance Commission (EAC)

Federal Voting Assistance Program (FVAP)

Election-related courses approved by the Election Administration and Certification Board

Have two years of continuous service in elections

Have a high school diploma or its equivalent

Submit a completed application for Initial Certification

Our process for developing training is interactive. By working with counties throughout the year, we at the state level learn which kinds of training county officials need. Then we build a training regimen with both instruction from state staff and peer-to-peer training.

The certification and training team that does this work within the state office includes a manager and four staff members. Two other staffers work collaboratively to deliver cyber resiliency reviews and cyber security training to ensure we are protected as a community. This group also identifies additional equipment that may be needed, which we help to provide to counties.

This team is also responsible for conducting county certification reviews, which are legally required every five years. This is a collaborative process in which the state office reviews procedures, identifies best practices, and shares information. We give awards based on these findings, and share them among all counties so they can learn from each other. This process also identifies issues that need to be addressed. Most often, such issues are resolved on-site. Anything left unaddressed during the review process is identified in the final report. This documentation ensures quality and consistency in practice. These reviews are taken to heart and are used as positive tools.

Finally, this team also serves as policy experts. Team members answer questions from localities when problems or confusion arise. They talk through situations, identify other counties that are experiencing similar challenges, and foster connections to help. This team is the heart and soul of policy and procedures, and the team members are seen as trusted partners as opposed to adversaries. 


\section{ELECTION LAW SupPorT}

We have an election law support team that spearheads an ongoing modernization process for all parts of the election system across the state, except tabulation. The modernization began when Secretary Wyman convened a technology summit of county auditors, election managers, and election information technology offices to determine the strengths of the current system, as well as the issues and challenges the state faces. Our voting technology was purchased with the original round of HAVA funds in the early 2000s. At that time, counties were given choices about equipment; like many places, our systems were not up to date.

We are set to go live with the modernization of our election system in April 2019. In every step of our modernization process, Washington's county officials have played meaningful roles. We have put a significant proportion of decision-making in the hands of county election administrators to ensure that what we deliver as a state is exactly what local officials want and need. We have also put significant procurement decision-making authority in the hands of technology experts. They identify business requirements, develop requests for proposals (RFPs), and make budget presentations.

Within this powerful, multi-year partnership, sometimes counties disagree. As a state office, we provide an open environment for tough, consensus-building discussions. This requires a significant investment of time and resources by the Office of Secretary of State and county officials, but this work pays off in the end.

\section{Voter INFORMATION SERVICES}

The Voter Information Services unit is designed to interact directly with voters and provides three major services. First, this team works with the counties to provide language support as needed. Second, staffers work with counties on candidate filings and help manage this process. Third, the group produces a statewide voter information pamphlet which is mailed to all of our voters to provide information to make ballot choices. Our voters love this guide. It reduces the number of calls to county offices during each election cycle, saving the counties valuable resources. This work is done by a manager and five staff members. Figure 14.1 shows the 2018 Voter Pamphlet in production. 


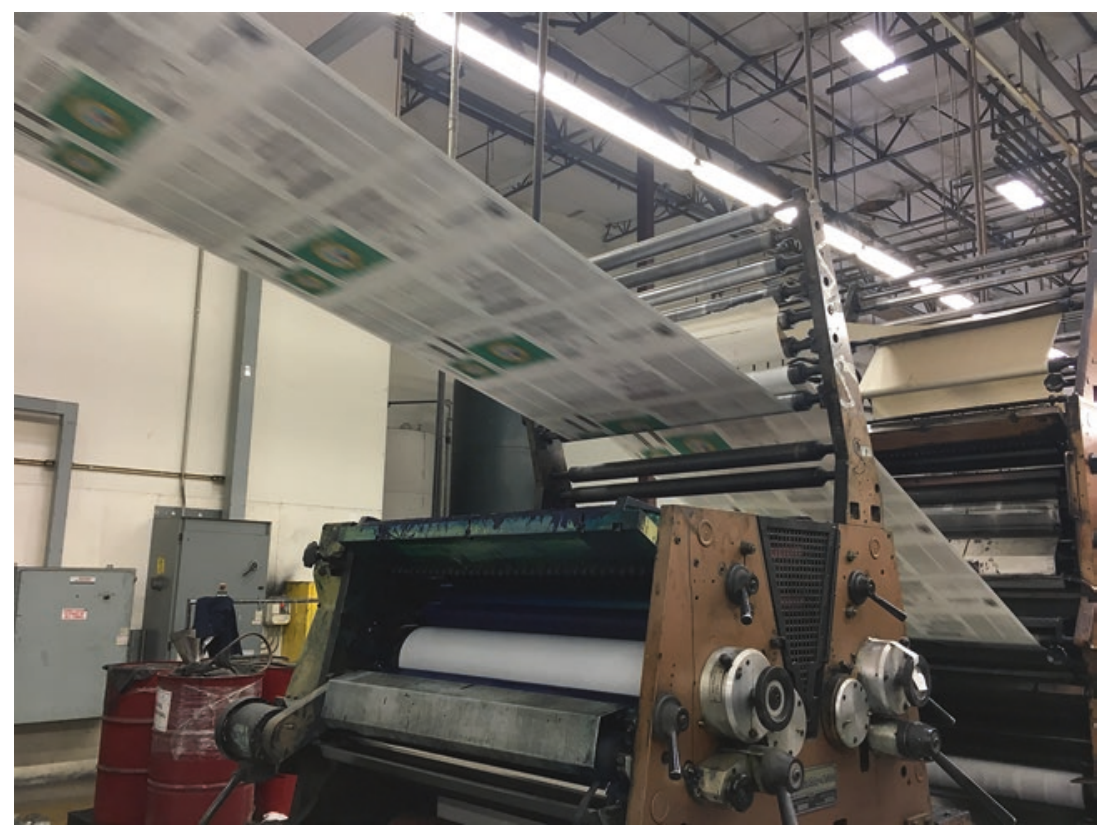

Fig. 14.1 2018 Voter pamphlet in production

\section{Other Efforts to Support Local Election Offices}

The Elections Division organizes several committees through which counties advise our services for voters. We have the opportunity to write state administrative code and to invite code review before it goes through public ratification. Our role is to vet proposals before they are formalized for public comment. Before we release proposals, we engage local officials through these committees to provide feedback. This gives local officials the opportunity to suggest language and provide other input at a critical point in the process.

As a local election official, I was inundated with emails from the office of the Secretary of State. To address the volume, we developed a regular email newsletter, the Washington State Elections Weekly, issued on Wednesdays. Through it, we brief local offices on any emerging issues and concisely explain in plain language what county election officials need to know that week. We also use this to brief people on what is happening in 


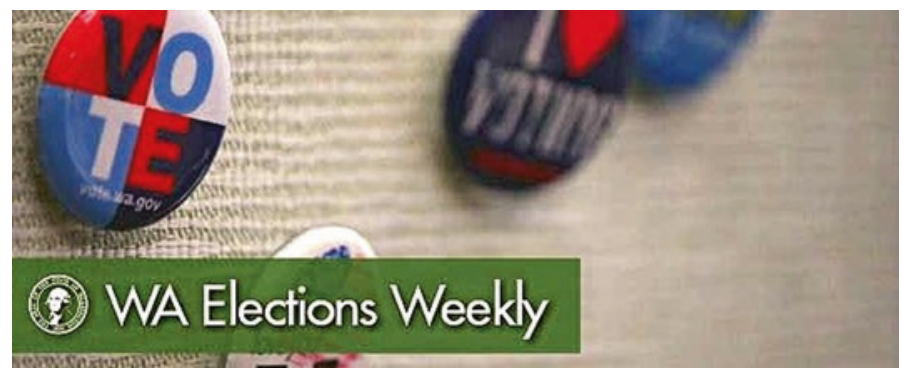

Fig. 14.2 Snapshot of Elections Weekly

the state election system, and to share questions and best practices across the state. This cuts down on email conversations and gives a single resource for county auditors to consult for information, with back issues available from 2013 onward. Fig. 14.2 shows a snapshot of Elections Weekly as it appears at the top of the email sent to local election officials.

We also host a weekly call each Thursday at 1 p.m. for live updates on the modernization project. I along with other Elections Division leaders use this weekly call to address other timely issues, address questions and concerns, and talk about whatever the local officials want to address. Local offices know that they have this regular opportunity to hear from us directly as well as communicate with each other.

\section{Advice for Other State Election Offices}

As the incoming President of the National Association of State Election Directors (NASED), I plan to share with other state election directors these successes that Washington has had in working with our county partner officials. When I have presented information about Washington at meetings in other states, I often hear from local officials asking me to discuss our approach with their state election directors about our focus on building camaraderie and trust to generate process improvements. I deeply appreciate the accomplishments of Washington's local officials. My opportunity with NASED is to help show the other state election directors that the time to build partnerships is worthwhile. It's not easy; it is an investment, but there is real benefit to true, meaningful collaborations through which state election directors share authority with county election officials. 
Open Access This chapter is licensed under the terms of the Creative Commons Attribution 4.0 International License (http://creativecommons.org/licenses/ by $/ 4.0 /$ ), which permits use, sharing, adaptation, distribution and reproduction in any medium or format, as long as you give appropriate credit to the original author(s) and the source, provide a link to the Creative Commons licence and indicate if changes were made.

The images or other third party material in this chapter are included in the chapter's Creative Commons licence, unless indicated otherwise in a credit line to the material. If material is not included in the chapter's Creative Commons licence and your intended use is not permitted by statutory regulation or exceeds the permitted use, you will need to obtain permission directly from the copyright holder. 